\title{
ANTERIOR CRUCIATE LIGAMENT RECONSTRUCTION WITH DOUBLE BUNDLE VERSUS SINGLE BUNDLE: EXPERIMENTAL STUDY
}

\author{
Roberto F. Mota e Albuquerque, Sandra Umeda Sasaki, Marco Martins \\ Amatuzzi, Fabio Janson Angelini
}

Mota e Albuquerque RF, Sasaki SU, Amatuzzi MM, Angelini, FJ. Anterior cruciate ligament reconstruction with double bundle versus single bundle: experimental study. Clinics. 2007;62(3):335-44.

OBJECTIVE: To test an intra-articular reconstruction of the anterior cruciate ligament of the knee in 10 human cadavers by replacing 2 anterior cruciate ligament bundles, with the purpose of producing a surrogate that would be structurally more similar to the anatomy of the anterior cruciate ligament and would provide the knee with more stability.

METHODS: We reconstructed the anteromedial and posterolateral bundles using a quadriceps muscle tendon graft that included a patellar bone segment. The anteromedial bundle was replaced in 10 knees (5 right and 5 left knees from different cadavers) by a quadriceps-bone tendon graft, and the anteromedial and posterolateral bundles were replaced in the matching pairs of these knees. In the latter, the bone segment was fixed to the tibia, and the tendinous portion of the graft was divided longitudinally creating two 5 -mm wide bundles that were inserted individually into the femur through 2 independent bone tunnels. Then, the knees were tested mechanically to evaluate the tibial anterior dislocation in relation to the femur, as well as the rigidity of the graft. The control group was formed by the knees with intact anterior cruciate ligaments, before being resected to be reconstructed.

RESULTS: The results obtained did not show superiority of double-bundle reconstruction over single-bundle reconstruction, and neither technique provided the knee with the same stability and rigidity of the intact anterior cruciate ligament.

CONCLUSION: Our hypothesis, based on the anatomy and biomechanics of the knee, that reconstruction of the anterior cruciate ligament using 2 bundles would result in a more anatomic reconstruction and provide better containment of the anterior tibial translation was not supported by the results of this study.

KEYWORDS: Anterior cruciate ligament. Knee. Biomechanics.

\section{INTRODUCTION}

Injuries to the anterior cruciate ligament (ACL) of the knee are frequent, mainly in young people and in the sports area, but may occur in all age groups. Surgical treatment is widely employed, consisting of anatomical or functional replacement of the ACL. Currently, intra-articular reconstruction techniques prevail, in which the ACL or one of its bundles is replaced with a graft fixed to femoral or tibial bone tunnels to stabilize the anterior knee. The anteromedial fasciculus of the ACL

Department of Orthopedics, Orthopedic and Traumatology Institute, Sao Paulo University, School of Medicine, Sao Paulo/SP, Brazil.

Email: rmotaa@uol.com.br

Received for publication on November 24, 2006.

Accepted for publication on January 29, 2007. is more relevant for the containment of the anterior drawer with the knee at a more pronounced flexion, close to $90^{\circ} .^{3}$ Because it has the most isometric behavior, it is the bundle chosen to be reproduced in reconstructions with single tunnels. ${ }^{4-10}$ However, it is known that the ACL has at least 2 anatomical bundles, the small anteromedial one and the posterolateral one, and that their mechanical and functional performances are different. ${ }^{1,3,5,10-17}$

The double tunnel technique in humans has been reported, with good results. ${ }^{20,22-24}$ However, most studies consist either of case series reports with no comparative control groups or of mere descriptions of the technique, such as technical notes. ${ }^{25-31}$

We developed an ACL reconstruction technique using a double femoral bone tunnel and a patellar bone-quadri- 
ceps tendon graft with its tendinous portion split longitudinally in an attempt to more accurately reproduce the normal anatomy of the anteromedial and posterolateral bundle. We compared this technique to widely employed conventional single-bundle technique. ${ }^{33}$

Our objective was to verify the magnitude of the repercussion of our double bundle technique on the final stability of the knee with regard to its possible transposition into the clinical practice.

\section{MATERIALS AND METHODS}

\section{Specimen collection, preparation, and preservation}

Our study included 20 anatomical specimens of knees from 10 fresh cadavers provided by the Death Verification Service of Sao Paulo City (Sao Paulo, SP - Brazil). The sex and racial composition were as follows: 7 males, 7 Caucasians, 2 mulattoes, and 1 Asian. The cause of death for all of them was some nonconsumptive disease. Their mean age was 46.9 years (range: 27-67 years).

Both knees of each cadaver were removed with all tissues, except the skin and subcutaneous cell tissue, 20 to $30 \mathrm{~cm}$ proximal and distally to the joint. All specimens were desiccated by removing muscles, vasa, nerves. The distal femoral segment and the proximal tibial segment, the lateral and medial ligamentous complexes, the cruciate ligaments, and the posterior capsule were preserved. The unit formed by the patella-quadriceps muscle tendon was desiccated separately, and the graft was extracted from the middle portion of the quadriceps tendon of each unit, with a patellar bone segment at the distal end (quadriceps-bone tendon graft). We then removed the tendinous fragment, which was $8 \mathrm{~cm}$ long, $1 \mathrm{~cm}$ wide, and $1 \mathrm{~cm}$ thick, as well as the bone fragment, which was $2.5 \mathrm{~cm}$ long, $1 \mathrm{~cm}$ wide, and $1 \mathrm{~cm}$ thick.

All specimens were identified, packed in plastic bags, and kept in the freezer at minus $20^{\circ} \mathrm{C}$ until tested (usually 2 weeks later). The quadriceps-bone tendon grafts were identified according to the knee they were removed from. To perform the tests, the grafts were left to defrost in isotonic saline $(0.9 \% \mathrm{NaCl}$ solution) for at least 2 hours at room temperature.

\section{Tests}

All knees were tested for tibial anterior dislocation in relation to the femur at $0^{\circ}, 30^{\circ}, 60^{\circ}$, and $90^{\circ}$ of knee flexion using a universal Kratos ${ }^{\circledR}$ Model k5002 testing machine equipped with a model MM $100 \mathrm{kgf}$ load cell and universal connection. The tests were documented using a 790 BBC Goerz Metrawatt Servogor graphic recorder to analyze the graphs of dislocation and rigidity of the system. The speed of application of the load adopted for all tests was $20 \mathrm{~mm} /$ minute.

The specimens were fixed to the machine by means of devices specially developed for the purpose. The femur was fixed near the base of the machine by means of a cylinder held by an adjustable vise, which allowed us to change the knee flexion angle, while the tibia was held by a cylinder directly and horizontally coupled to the load cell (Figure 1). Uniform movement was applied until a $100 \mathrm{~N}$ load was achieved at $0^{\circ}, 30^{\circ}, 60^{\circ}$, and $90^{\circ}$ of knee flexion, with 4 repetitions at each degree of flexion. The results shown in the tables are the means of the last 3 repetitions.

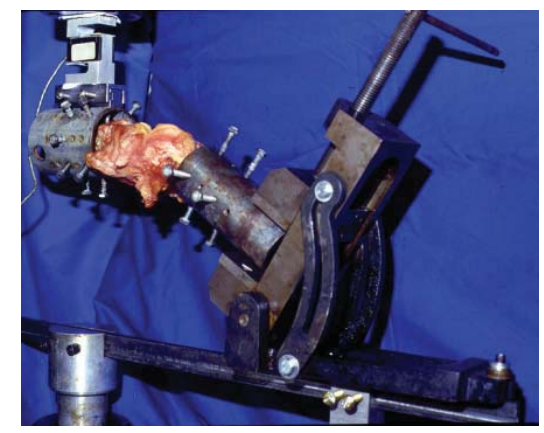

Figure 1 - Adjustable device with knee in $30^{\circ}$ flexion

Reconstruction tests for the ACL were performed with paired single- or double-femoral tunnels so that each knee subjected to each reconstruction technique was compared with its contralateral pair that was reconstructed using the other technique. Each pair of knees subjected to testing was alternated with regard to the side subjected to a each different (double or single bundle) reconstruction technique for the purpose of preventing any involuntary technical differences related to the operated side.

The graft used in each operation was always taken from the operated knee itself. The control group consisted of the same knees with their intact ligaments, prior to the surgical procedures. Thus, each of the 20 knees was tested twice-once with the intact ACL and once after its resection and reconstruction using either technique studied. The test record of 1 knee was damaged, which prevented us from tabulating the results for this test.

Following the initial series of tests with intact knees, the specimens were divided into 2 groups of 10 knees each. The anterior cruciate ligaments were then resected in both groups.

The anterior cruciate ligaments of the knees in Group I were reconstructed with a 10 -mm diameter quadricepsbone tendon graft through single tibial and femoral tunnels and fixed to the femur and tibia at points that were respectively $1 \mathrm{~cm}$ proximal and $1 \mathrm{~cm}$ distal to the extraarticular holes using Ethibond \# 5 thread anchored to a 
bicortical screw with washer. The bone fragment of the graft was positioned into the tibial tunnel using 2 Ethibond \# 5 threads through the bone. The tendinous end was fixed to the tunnel using Krackow-type ${ }^{34,35}$ sutures and Ethibond \# 5 (braided polyester thread).

The anterior cruciate ligaments of the knees in Group II were reconstructed with 10-mm wide quadriceps-bone tendon graft. The tibial tunnel and the fixation of the bone fragment to this tunnel were identical with those in Group I, and the tendinous segment of the graft was divided longitudinally into two 5-mm wide segments (Figure 2) that were individually fixed to the femur through individual tunnels drilled in them, reproducing the ACL anteromedial and posterolateral bundles.

The grafts of both groups were placed on a preparation table and subjected to longitudinal tension by the fixing threads in order to accommodate the sutures into the graft (Figure 3).

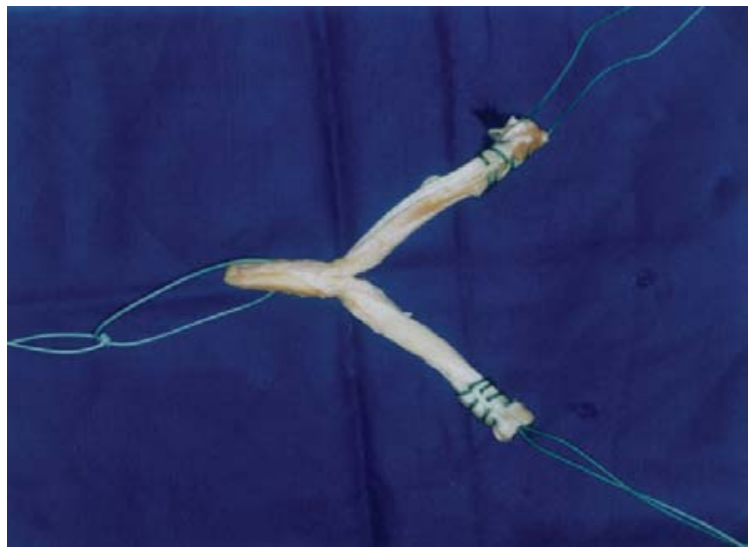

Figure 2 - Quadriceps-bone tendon graft, double bundle

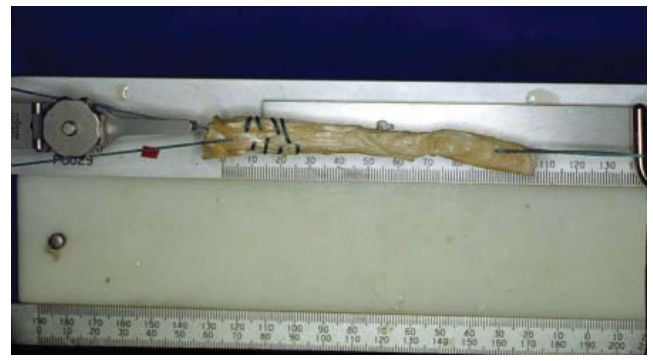

Figure 3 - Graft tensioned in preparation table

\section{The surgeries}

Each desiccated anatomical specimen was fixed to a stainless steel table by means of a vise where the tibial distal end was attached. Initially, the ACL was inspected for integrity and identification of its anteromedial and posterolateral bundles. The ligament was then resected (Figure 4).

A $10-\mathrm{mm}$ tibial tunnel was drilled, with the tunnel centered $5 \mathrm{~mm}$ anterior to the medial intercondylar tuber-

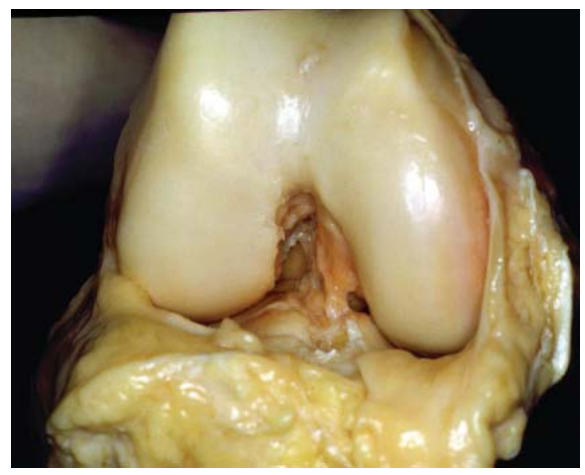

Figure 4 - ACL resected

cle. The next steps varied according to the reconstruction technique employed, except for the passage of the graft and its fixation to the tibial tunnel. Once the femoral tunnel was drilled, the graft was passed through it, pulled by the suture threads of the tendinous end and leaving the bone-tendon transition in the articular hole of the tunnel. The graft bone fragment was then anchored into the tibial metaphysis by means of suture threads to a bicortical screw at a point approximately $1 \mathrm{~cm}$ distal to the external tibial hole.

\section{Reconstruction using a single bundle and femoral tunnel}

A 10-mm femoral tunnel was drilled in the lateral wall of the intercondylar notch, $30^{\circ}$ from the central position and leaving a $2-\mathrm{mm}$ posterior wall. The graft was then passed through the tibial and femoral bone tunnels, and the tendinous end was fixed under tension to the femur with the knee at $30^{\circ}$ of flexion after fixing the bone end to the tibia as described above. Tension was provided by manually tensioning the suture threads.

\section{Reconstruction with double bundle and femoral tunnel}

The first femoral tunnel was placed in the same position as in the single-bundle technique but was only $6 \mathrm{~mm}$ in diameter. The second femoral tunnel was drilled in a posterior-inferior position $2 \mathrm{~mm}$ from the first, with a divergent orientation. In this way, we produced 2 points of femoral insertion separated by a distance of $2 \mathrm{~mm}$ and with a wall between the tunnels that was thicker than that between the articular holes, preventing the risk of rupturing the wall that separated the tunnels. The first tunnel is conventionally used in ACL reconstructions and was drilled in the single femoral tunnel group; the second tunnel was drilled in an immediately posterior-inferior position and reproduces the femoral origin of the ACL posterolateral bundle as described by Girgis et al. ${ }^{3}$ The graft was then passed through the bone tunnels, and the 2 tendinous ends were fixed un- 
der tension to the femur at $30^{\circ}$ of knee flexion, following the fixation of the bone end to the tibia. The anterior bundle was passed through the first femoral tunnel, and the posterior bundle was passed through the second tunnel, more posterior and more laterally than the first one. First, we fixed the anteromedial tunnel bundle, followed by fixation of the posterolateral tunnel bundle. Tension was provided by manually tensioning the suture threads.

\section{Statistical analysis}

A basic descriptive statistical analysis was performed of the quantitative parameters, anterior dislocation and rigidity. For parametric intergroup comparisons, we used paired and unpaired Student $t$ tests. For nonparametric intergroup comparisons, we used the Wilcoxon and MannWhitney $U$ tests. In all cases we adopted a $5 \%$ significance level $(\alpha=0.05)$.

\section{RESULTS}

The test results concerning tibial anterior dislocation in relation to the femur at $0^{\circ}, 30^{\circ}, 60^{\circ}$, and $90^{\circ}$ of knee flexion showed that the dislocation was more pronounced after resection of the anterior cruciate ligament (ACL) and its re- construction than with the intact ACL (Table 1). Dislocation was the same after single- or double-bundle reconstruction and was more pronounced compared to the intact ACL.

The results of rigidity tests $(\mathrm{kN} / \mathrm{m})$ at $0^{\circ}, 30^{\circ}, 60^{\circ}$, and $90^{\circ}$ of knee flexion show that rigidity was less pronounced after ACL resection and reconstruction than with the intact ACL at the 4 angles of knee flexion (Table 2).

Tests for tibial anterior dislocation differences in relation to the femur, as well as for rigidity at $0^{\circ}, 30^{\circ}, 60^{\circ}$, and $90^{\circ}$ of knee flexion showed that there was no change as a function of the reconstruction technique employed $(P$ $=.57, P=.8356, P=.4401$ and $P=.6104$, respectively, for dislocation, and $P=.1416, P=.2062, P=.4581$ and $P=.2892$, respectively, for rigidity) (Tables 3 and 4 ).

\section{DISCUSSION}

\section{Techniques and Grafts}

Intra-articular ACL reconstruction is a well established procedure, being currently the most widely used technique in the surgical treatment of anterior instability of the knee. The results are good in approximately $90 \%$ of cases. ${ }^{6,7,36-49}$ However, the replacement of the ACL with a graft using a single bundle of fibers and single insertions into the tibia

Table 1 - Anterior dislocation at $0^{\circ}, 30^{\circ}, 60^{\circ}$, and $90^{\circ}$ flexion in knees subjected to reconstruction with single and double femoral tunnels preceded by their respective controls with intact anterior cruciate ligament (ACL)

\begin{tabular}{|c|c|c|c|c|}
\hline & $\begin{array}{l}\text { Single Femoral Tunnel } \\
\text { Intact ACL } \\
\text { Anterior dislocation }(\mathrm{mm}) \text { at } 0^{\circ}\end{array}$ & Reconstructed & $\begin{array}{l}\text { Double Femoral Tunnel } \\
\text { Intact ACL }\end{array}$ & Reconstructed \\
\hline M & $2.61 *$ & 5.32 & $1.84^{\dagger}$ & 5.12 \\
\hline SD & 1.31 & 1.78 & 0.52 & 2.02 \\
\hline SEM & 0.44 & 0.59 & 0.16 & 0.64 \\
\hline Min & 1.07 & 2.78 & 1.17 & 2.60 \\
\hline Max & 5.47 & 9.20 & 2.87 & 8.87 \\
\hline $\begin{array}{l}\text { M } \\
\text { SD } \\
\text { SEM } \\
\text { Min } \\
\text { Max }\end{array}$ & $\begin{array}{l}\text { Anterior dislocation }(\mathrm{mm}) \text { at } 30^{\circ} \\
2.32^{\ddagger} \\
0.84 \\
0.28 \\
1.53 \\
3.80\end{array}$ & $\begin{array}{l}4.40 \\
0.55 \\
0.18 \\
3.78 \\
5.47\end{array}$ & $\begin{array}{l}2.09^{\S} \\
0.80 \\
0.25 \\
1.47 \\
3.93\end{array}$ & $\begin{array}{l}4.68 \\
1.09 \\
0.34 \\
2.67 \\
6.00\end{array}$ \\
\hline $\begin{array}{l}\text { M } \\
\text { SD } \\
\text { SEM } \\
\text { Min } \\
\text { Max }\end{array}$ & $\begin{array}{l}\text { Anterior dislocation }(\mathrm{mm}) \text { at } 60^{\circ} \\
2.70^{\|} \\
1.45 \\
0.48 \\
1.67 \\
6.0\end{array}$ & $\begin{array}{l}3.77 \\
0.61 \\
0.20 \\
2.47 \\
4.5\end{array}$ & $\begin{array}{l}2.20^{\pi} \\
0.54 \\
0.17 \\
1.67 \\
3.27\end{array}$ & $\begin{array}{l}3.71 \\
0.74 \\
0.23 \\
2.40 \\
4.60\end{array}$ \\
\hline $\begin{array}{l}\text { M } \\
\text { SD } \\
\text { SEM } \\
\text { Min } \\
\text { Max }\end{array}$ & $\begin{array}{l}\text { Anterior dislocation }(\mathrm{mm}) \text { at } 90^{\circ} \\
2.26^{* *} \\
0.67 \\
0.22 \\
1.60 \\
3.33\end{array}$ & $\begin{array}{l}3.32 \\
0.88 \\
0.29 \\
1.80 \\
4.40\end{array}$ & $\begin{array}{l}2.05^{\dagger \dagger} \\
0.94 \\
0.30 \\
1.11 \\
4.53\end{array}$ & $\begin{array}{l}3.40 \\
0.60 \\
0.19 \\
2.27 \\
4.20\end{array}$ \\
\hline
\end{tabular}

M: mean; SD: standard deviation; SEM: standard error of the mean; Min: minimum; Max: maximum. $* P=.019 ;{ }^{\dagger} P=.002 ;{ }^{\ddagger} P=.004 ;{ }^{\S} P=.002 ; \| P=.055$; I $P=.001 ;{ }^{* *} P=.02 ;{ }^{\dagger} P=.03$. 
Table 2 - Rigidity at $0^{\circ}, 30^{\circ}, 60^{\circ}$, and $90^{\circ}$ of flexion in knees subjected to reconstruction with single and double femoral tunnels preceded by their respective controls with intact anterior cruciate ligament (ACL)

\begin{tabular}{|c|c|c|c|c|}
\hline & $\begin{array}{l}\text { Single Femoral Tunnel } \\
\text { Intact ACL } \\
\text { Rigidity }(\mathrm{kN} / \mathrm{m}) \text { at } 0^{\circ}\end{array}$ & Reconstructed & $\begin{array}{l}\text { Double Femoral Tunnel } \\
\text { Intact ACL }\end{array}$ & Reconstructed \\
\hline M & $53.90 *$ & 28.14 & $61.75^{\dagger}$ & 26.97 \\
\hline SD & 14.78 & 3.93 & 11.94 & 6.23 \\
\hline SEM & 4.93 & 1.31 & 3.78 & 1.97 \\
\hline Min & 32.02 & 19.10 & 47.56 & 15.68 \\
\hline \multirow[t]{2}{*}{ Max } & 87.20 & 33.48 & 86.89 & 35.93 \\
\hline & Rigidity $(\mathrm{kN} / \mathrm{m})$ at $30^{\circ}$ & & & \\
\hline M & $49.98^{\ddagger}$ & 26.97 & $54.42^{\S}$ & 26.51 \\
\hline SD & 6.97 & 1.79 & 10.27 & 6.38 \\
\hline SEM & 2.32 & 0.60 & 3.25 & 2.02 \\
\hline Min & 40.88 & 24.57 & 35.93 & 20.73 \\
\hline \multirow[t]{2}{*}{ Max } & 61.31 & 30.20 & 67.15 & 42.11 \\
\hline & Rigidity $(\mathrm{kN} / \mathrm{m})$ at $60^{\circ}$ & & & \\
\hline M & $46.96^{\|}$ & 30.71 & $50.14^{\pi}$ & 30.35 \\
\hline SD & 10.27 & 4.24 & 8.41 & 5.36 \\
\hline SEM & 3.42 & 1.41 & 2.66 & 1.70 \\
\hline Min & 26.77 & 25.86 & 35.16 & 24.96 \\
\hline \multirow[t]{2}{*}{ Max } & 59.04 & 40.02 & 61.31 & 40.88 \\
\hline & Rigidity $(\mathrm{kN} / \mathrm{m})$ at $90^{\circ}$ & & & \\
\hline M & $49.13^{* *}$ & 33.92 & $53.99^{\dagger \dagger}$ & 31.81 \\
\hline SD & 7.90 & 9.59 & 15.34 & 5.64 \\
\hline SEM & 2.63 & 3.20 & 4.85 & 1.79 \\
\hline Min & 37.73 & 24.21 & 27.31 & 27.25 \\
\hline Max & 61.31 & 54.50 & 84.09 & 43.60 \\
\hline
\end{tabular}

M: mean; SD: standard deviation; SEM: standard error of the mean; Min: minimum; Max: maximum. ${ }^{*} P<.001 ;{ }^{\dagger} P<.001 ;{ }^{\ddagger} P<.001 ;{ }^{\circledR} P<.001 ;{ }^{\|} P<$ $.001 ;{ }^{\sharp} P<.001 ;{ }^{* *} P=.009 ;{ }^{\dagger \dagger} P<.001$

Table 3 - Difference between anterior dislocation before (intact ligament) and after anterior cruciate ligament (ACL) reconstruction at $0^{\circ}, 30^{\circ}, 60^{\circ}$, and $90^{\circ}$ of flexion in knees subjected to the technique using single and double femoral tunnel

\begin{tabular}{lll}
\hline & $\begin{array}{l}\text { Single Femoral Tunnel } \\
\text { Anterior dislocation }(\mathrm{mm}) \text { at } 0^{\circ}\end{array}$ & Double Femoral Tunnel \\
\hline M & $(2.71)^{*}$ & $(3.28)$ \\
SD & 2.37 & 1.87 \\
SEM & 0.79 & 0.59 \\
Min & $(7.33)$ & $(6.67)$ \\
Max & 0.60 & $(1.43)$ \\
& Anterior dislocation difference $(\mathrm{mm})$ at & $30^{\circ}$ \\
M & $(2.08)^{\dagger}$ & $(2.59)$ \\
SD & 0.76 & 1.29 \\
SEM & 0.25 & 0.41 \\
Min & $(2.87)$ & $(4.07)$ \\
Max & $(0.53)$ & $(0.07)$ \\
& Anterior dislocation difference $(\mathrm{mm})$ at & $60^{\circ}$ \\
M & $(1.07)^{\ddagger}$ & $(1.51)$ \\
SD & 1.42 & 0.99 \\
SEM & 0.47 & 0.31 \\
Min & $(2.47)$ & $(2.87)$ \\
Max & 2.07 & 0.60 \\
& Anterior dislocation difference (mm) at $90^{\circ}$ \\
M & $(1.07)^{\S}$ & $(1.35)$ \\
SD & 1.10 & 1.23 \\
SEM & 0.37 & 0.39 \\
Min & $(2.40)$ & $(2.53)$ \\
Max & 1.00 & 1.87 \\
\hline
\end{tabular}

M: mean; SD: standard deviation; SEM: standard error of the mean; Min: minimum; Max: maximum. ${ }^{*} P=.57 ;{ }^{\dagger} P=.84 ;{ }^{\ddagger} P=.44 ;{ }^{\circledR} P=.61$ and the femur certainly does not fully reproduce the anatomy and function of the original ACL. $13,4,10,12-19,21,22$ Thus we tested an ACL replacement technique using a graft with 2 bundles of fibers and 2 sites of insertion into the femur.

Although some authors do not accept the existence of 2 or 3 anatomical fasciculi in the ACL, ${ }^{12,18}$ there is a consensus on the concept that different parts of the ligament behave differently at different angles of knee flexion. In our study, we could observe macroscopically the presence of these two fasciculi. In general, authors agree that the posterolateral bundle, ie, the most posterior portion of the ACL, becomes tensioned as the knee approaches extension and relaxes as the knee bends. ${ }^{4,5,12,18}$ Its stabilizing function occurs mainly in the first $45^{\circ}$ of flexion, where it alone accounts for up to $47 \%$ the resistance to tibial anterior dislocation, according to Amis and Dawkins. ${ }^{4}$ Although Takai et $\mathrm{a}^{17}$ have found the two bundles equally dividing the tension with the extended knee, the great majority of authors recognize that the involvement of the ACL anteromedial bundle in the first $30^{\circ}$ to $45^{\circ}$ of flexion is secondary to that of the posterolateral bundle., ${ }^{4,5,12,18}$ However, the near-isometric behavior of the anteromedial bundle is commonly observed, and this is the reason why its reproduction is recommended in single-bundle reconstructions.

It seems evident that, at least from a functional perspec- 
Table 4 - Difference between rigidity before (intact ligament) and after anterior cruciate ligament (ACL) reconstruction at $0^{\circ}, 30^{\circ}, 60^{\circ}$, and $90^{\circ}$ of flexion in knees subjected to the technique using single and double femoral tunnel

\begin{tabular}{lll}
\hline & $\begin{array}{l}\text { Single Femoral Tunnel } \\
\text { Rigidity difference }(\mathrm{kN} / \mathrm{m}) \text { at } 0^{\circ}\end{array}$ & \\
\hline M & $25.77^{*}$ & 34.78 \\
SD & 14.95 & 10.36 \\
SEM & 4.98 & 3.28 \\
Min & 4.23 & 20.84 \\
Max & 58.28 & 51.57 \\
& Rigidity difference $(\mathrm{kN} / \mathrm{m})$ at $30^{\circ}$ & \\
M & $23.00^{\dagger}$ & 27.91 \\
SD & 6.51 & 9.33 \\
SEM & 2.17 & 2.95 \\
Min & 14.72 & 14.58 \\
Max & 34.97 & 38.89 \\
& Rigidity difference $(\mathrm{kN} / \mathrm{m})$ at $60^{\circ}$ & \\
M & $16.25^{\ddagger}$ & 19.79 \\
SD & 9.53 & 10.66 \\
SEM & $3.18 b$ & 3.37 \\
Min & 0.91 & $(3.62)$ \\
Max & 29.52 & 36.36 \\
& Rigidity difference $(\mathrm{kN} / \mathrm{m})$ at $90^{\circ}$ & \\
M & $15.21^{\S}$ & 22.18 \\
SD & 13.24 & 14.41 \\
SEM & 4.41 & 45.56 \\
Min & $(12.98)$ & $(10.57)$ \\
Max & 26.66 & 47.30 \\
\hline
\end{tabular}

M: mean; SD: standard deviation; SEM: standard error of the mean; Min: minimum; Max: maximum. ${ }^{*} P=.14 ;{ }^{\dagger} P=.21 ;{ }^{\ddagger} P=.46 ;{ }^{\circledR} P=.29$

tive, the ACL has multiple bundles and that, although the reconstruction of a single bundle can stabilize the knee in the anterior direction in the sagittal plane, it will not fully reproduce the anatomy and function of the ACL. Therefore, the reproduction of the two functionally most important bundles, regardless of the divergences concerning their relative contributions to knee stabilization, aims at improving the ACL reconstruction technique so that it approaches the normal functional anatomy of this ligament.

The isometricity (positioning) of the graft has been widely studied, ${ }^{5,9,50-52}$ and the replacement of the anteromedial bundle best approaches this position. The reproduction of the posterolateral bundle, although less isometric, could contribute to the global isometricity of the reconstruction, since it becomes more tensioned in the positions where the anteromedial bundle would be more relaxed, thus playing a complementary role and making the resulting tension on the graft less variable.

Although the ACL anatomy and function have been widely studied, publications dealing with replacement of more than 1 ligament bundle are mostly descriptions of techniques ${ }^{25-31}$ or case series reports. ${ }^{20,22-24}$

Most authors make use of semitendinous and gracilis tendon grafts ${ }^{24-26,28-30,32}$ or alografts. ${ }^{23,25}$ Our study used the quadriceps-bone tendon graft, which, although not the most frequently used for ACL primary reconstructions, has mechanical characteristics that are superior to those of the patellar ligament graft $^{54-59}$ and is used mainly in revision operations and complex knee injury reconstructions involving both cruciate ligaments. ${ }^{60}$ The quadriceps tendon graft seemed to us appropriate for this study because of the fact that it has bone in one end and, in the other, a tendon that is thicker than the patellar ligament. Therefore, in the double femoral tunnel reconstructions, the tendinous end was longitudinally divided into 2 bundles that were thicker than the one that would be obtained using the flat, thin patellar ligament. ${ }^{55,56,58}$

At other end, the bone fragment fixed to the tibial tunnel provides a common single base for the tensioning of the 2 tendinous bundles, which simplifies the technique and reduces the number of required fixations. To the best of our knowledge there is only 1 published report that used the same graft for double-bundle reconstruction. ${ }^{31}$

The reconstruction technique derives from the original technique of Jones ${ }^{61}$ that was standardized in the US by Clancy et $\mathrm{al}^{7}$ and in Europe by Dejour. ${ }^{62-64}$ Besides using the quadriceps-bone tendon graft, we introduced a technical change in the femoral double tunnel series, in which the first tunnel was drilled as in the original technique and a second tunnel was drilled distally, posteriorly, and laterally to the first in a position corresponding to the ACL posterolateral bundle, ${ }^{3,4}$ thus reproducing the two main ACL bundles, ie, the anteromedial and the posterolateral bundles.

\section{Dislocation and Rigidity}

The large variation in the mechanical properties of ligaments and tendons observed in this study is also documented in literature by authors such as Rossi et al ${ }^{65}$ and Noyes et al. ${ }^{66}$ In both operated groups of our study, the median anterior dislocation was larger than that in the control group at all angles of flexion except in single-bundle reconstructed knees at $60^{\circ}$ of knee flexion, which stayed in the significance level limit. Also concerning rigidity, the behavior of both groups was similar, but the control group showed lower values at all positions. Our results are consistent with those achieved by Chao et al, ${ }^{22}$ Radford et al, ${ }^{53}$ and Guanche et al, ${ }^{14}$ who observed major differences in the behavior of knees undergoing single-bundle and doublebundle reconstruction compared to the knee with an intact ACL. On the other hand, Miura et al ${ }^{67}$ recently reproduced knee strength similar to that of the intact ACL.

Regarding the comparison between the operated 
groups, we used the difference between the results from each operated knee and its control since, although we used paired tests, we observed large variability in the behavior of the left and right knees of the same cadavers in the control group. We noticed that the use of a double bundle in ACL reconstruction did not contribute to reduced tibial anterior dislocation when compared with single-bundle reconstruction in any of the angles of knee flexion. Also, there were no differences concerning rigidity between the two groups. Chao et $\mathrm{al}^{22}$ and Guanche et $\mathrm{al},{ }^{14}$ studying human knees, and Radford et al ${ }^{53}$ studying animals, had similar results; however, Guanche et al. ${ }^{14}$ using a double bundle with distinct bone tunnels both in the femur and the tibia, obtained tension levels that were not necessarily expressed in tibial anterior dislocation and were similar to anteromedial bundle of the intact ACL. Muneta et $\mathrm{al}^{20}$ presented positive preliminary clinical results concerning double-bundle reconstruction.

Therefore, although the anatomy and biomechanics of the knee indicated that reconstructing the ACL with 2 bun- dles with the intent of making a more isometric reconstruction would result in better containment of the anterior tibial translation, our results did not support this supposition.

\section{CONCLUSION}

We conclude that anterior cruciate ligament reconstruction, both using single-bundle and double-bundle techniques, provides less rigidity and will not reestablish the ability to contain the tibial anterior dislocation in comparison with the intact ligament of the control group at $0^{\circ}, 30^{\circ}$, $60^{\circ}$, and $90^{\circ}$ of knee flexion exposed to a $100 \mathrm{~N}$ force. Anterior cruciate ligament reconstruction with a double bundle reproducing the anteromedial bundle and the posterolateral bundle is not superior to the reconstruction with single bundle reproducing the anteromedial bundle, in terms of reduction of the tibial anterior dislocation at $0^{\circ}, 30^{\circ}, 60^{\circ}$, and $90^{\circ}$ of knee flexion exposed to a $100 \mathrm{~N}$ force and in terms of rigidity under the same conditions.

\section{RESUMO}

Mota e Albuquerque RF, Sasaki SU, Amatuzzi MM, Angelini, FJ Reconstrução do ligamento cruzado anterior com duplo feixe versus feixe único: estudo experimental. Clinics. 2007;62(3):335-44.

OBJETIVO: Testar uma técnica de reconstrução intra-articular do ligamento cruzado anterior do joelho em 10 cadáveres humanos com substituição de dois feixes do ligamento cruzado anterior, com objetivo de produzir um substituto estruturalmente mais semelhante à anatomia do ligamento cruzado anterior e que conferisse maior estabilidade ao joelho.

MÉTODOS: Os feixes ântero-medial e póstero-lateral foram reconstruídos com um enxerto de tendão do músculo quadríceps da coxa, incluindo um segmento ósseo patelar. Dez joelhos (cinco direitos e cinco esquerdos de cadáveres 
diferentes) tiveram o feixe ântero-medial substituído por um enxerto de tendão quadricipital-osso e, nos pares desses joelhos, foram substituídos o feixe ântero-medial e o pósterolateral. Nestes últimos, o segmento ósseo foi fixado na tíbia e a parte tendinosa do enxerto foi dividida longitudinalmente, dando origem a dois feixes de $5 \mathrm{~mm}$ de largura, que foram inseridos separadamente no fêmur através de dois túneis ósseos independentes. Os joelhos foram então submetidos a ensaios mecânicos, nos quais avaliamos o deslocamento anterior da tíbia em relação ao fêmur e a rigidez do enxerto. Os joelhos com ligamento cruzado anterior íntegro, antes de sua ressecção para a realização das reconstruções, formaram o grupo controle.

RESULTADOS: Os resultados obtidos não mostraram superioridade da reconstrução com duplo feixe sobre a reconstrução com feixe único e nenhuma delas conferiu ao joelho a mesma estabilidade e rigidez do ligamento cruzado anterior íntegro.

CONCLUSÃO: Apesar de encontrarmos na anatomia e na biomecânica do joelho razões para procurarmos reconstruir o ligamento cruzado anterior com dois feixes, no intuito de tornar a sua reconstrução mais anatômica, proporcionando uma melhor contenção da translação anterior da tíbia, não conseguimos, com os nossos resultados, justificar a utilização da técnica estudada.

UNITERMOS: Ligamento cruzado anterior. Joelho. Cadáver. Biomecânica.

\section{REFERENCES}

1. Dodds JA, Arnoczky SP. Anatomy of the anterior cruciate ligament: a blueprint for repair and reconstruction. Arthroscopy. 1994;10:132-9.

2. Butler DL, Noyes FR, Grood ES. Ligamentous restraints to anteriorposterior drawer in the human knee. A biomechanical study. J Bone Joint Surg Am. 1980;62:259-70.

3. Girgis FG, Marshall JL, Monajem A. The cruciate ligaments of the knee joint. Anatomical, functional and experimental analysis. Clin Orthop Relat Res. 1975;106:216-31.

4. Amis AA, Dawkins GP. Functional anatomy of the anterior cruciate ligament. Fibre bundle actions related to ligament replacements and injuries. J Bone Joint Surg Br. 1991;73:260-7.

5. Arms SW, Pope MH, Johnson RJ, Fischer RA, Arvidsson I, Eriksson E. The biomechanics of anterior cruciate ligament rehabilitation and reconstruction. Am J Sports Med. 1984;12:8-18.

6. Clancy WG Jr. Anterior cruciate ligament functional instability. A static intra-articular and dynamic extra-articular procedure. Clin Orthop Relat Res. 1983;172:102-6.

7. Clancy WG Jr, Nelson DA, Reider B, Narechania RG. Anterior cruciate ligament reconstruction using one-third of the patellar ligament, augmented by extra-articular tendon transfers. J Bone Joint Surg Am. 1982;64:352-9.

8. Friedman RL, Feagin JA Jr. Topographical anatomy of the intercondylar roof. A pilot study. Clin Orthop Relat Res. 1994;306:163-70.

9. Hoogland T, Hillen B. Intra-articular reconstruction of the anterior cruciate ligament. An experimental study of length changes in different ligament reconstructions. Clin Orthop Relat Res. 1984;185:197-202.

10. Sakane M, Fox RJ, Woo SL, Livesay GA, Li G, Fu FH. In situ forces in the anterior cruciate ligament and its bundles in response to anterior tibial loads. J Orthop Res. 1997;15:285-93.

11. Burnett QM 2nd, Fowler PJ. Reconstruction of the anterior cruciate ligament: historical overview. Orthop Clin North Am. 1985;16:143-57.
12. Arnoczky SP. Anatomy of the anterior cruciate ligament. Clin Orthop Relat Res. 1983;172:19-25.

13. Bach JM, Hull ML, Patterson HA. Direct measurement of strain in the posterolateral bundle of the anterior cruciate ligament. J Biomech. 1997;30:281-3.

14. Guanche CA, Thomas KA, Edwards TB, Petrie SG, Nguyen GT. Dual limb grafts in anterior cruciate ligament reconstruction. In: American Association Orthopaedic Surgery. Annual Meeting - Scientific Program, 1997. San Francisco, California; 1997.

15. Mommersteeg TJ, Huiskes R, Blankevoort L, Kooloos JG, Kauer JM. An inverse dynamics modeling approach to determine the restraining function of human knee ligament bundles. J Biomech. 1997;30:139-46.

16. Mommersteeg TJ, Kooloos JG, Blankevoort L, Kauer JM, Huiskes R, Roeling FQ. The fibre bundle anatomy of human cruciate ligaments. J Anat. 1995;187 ( Pt 2):461-71.

17. Takai S, Woo SL, Livesay GA, Adams DJ, Fu FH. Determination of the in situ loads on the human anterior cruciate ligament. J Orthop Res. 1993;11:686-95.

18. Friederich NF, Müller W, O'Brien WR. Klinische Anwendung biomechanischer und funktionell anatomischer Daten am Kniegelenk. [Clinical application of biomechanic and functional anatomical findings of the knee joint]. Orthopade. 1992;21:41-50.

19. Norwood LA, Cross MJ. Anterior cruciate ligament: functional anatomy of its bundles in rotatory instabilities. Am J Sports Med. 1979;7:23-6.

20. Muneta T, Sekiya I, Ogiuchi T, Yagishita K, Yamamoto H. Two-bundle anatomic reconstruction of the anterior cruciate ligament using semitendinosus tendon with endobuttons: a preliminary report. In: American Association Orthopaedic Surgery. Annual Meeting - Scientific Program, 1998. New Orleans, Louisiana; 1998.

21. Mommersteeg TJ, Blankevoort L, Huiskes R, Kooloos JG, Kauer JM. Characterization of the mechanical behavior of human knee ligaments: a numerical-experimental approach. J Biomech. 1996;29:151-60. 
22. Chao TT, Lew WD, Lewis JL, Lindquist C, Hong B, Arendt E. Biomechanical effect of a two-segment anterior cruciate ligament graft with separate femoral attachments and differing levels of prescribed load sharing. J Orthop Res. 1992;10:868-77.

23. Nyland J, Caborn DN, Rothbauer J, Kocabey Y, Couch J. Two-year outcomes following ACL reconstruction with allograft tibialis anterior tendons: a retrospective study. Knee Surg Sports Traumatol Arthrosc. $2003 ; 11: 212-8$

24. Kubo T, Hara K, Suginoshita T, Shimizu C, Tsujihara T, Honda H, et al. Anterior cruciate ligament reconstruction using the double bundle method. J Orthop Surg (Hong Kong). 2000;8:59-63.

25. Cha PS, Brucker PU, West RV, Zelle BA, Yagi M, Kurosaka M, et al. Arthroscopic double-bundle anterior cruciate ligament reconstruction: an anatomic approach. Arthroscopy. 2005;21:1275.

26. Hara K, Arai Y, Ohta M, Minami G, Urade H, Hirai N, et al. A new double-bundle anterior cruciate ligament reconstruction using the posteromedial portal technique with hamstrings. Arthroscopy. 2005;21(:1274

27. Caborn DN, Chang HC. Single femoral socket double-bundle anterior cruciate ligament reconstruction using tibialis anterior tendon: description of a new technique. Arthroscopy. 2005;21(:1273.

28. Bellier G, Christel P, Colombet P, Djian P, Franceschi JP, Sbihi A. Doublestranded hamstring graft for anterior cruciate ligament reconstruction. Arthroscopy. 2004; 20:890-4.

29. Takeuchi R, Saito T, Mituhashi S, Suzuki E, Yamada I, Koshino T Double-bundle anatomic anterior cruciate ligament reconstruction using bone-hamstring-bone composite graft. Arthroscopy. 2002;18:550-5.

30. Hara K, Kubo T, Suginoshita T, Shimizu C, Hirasawa Y. Reconstruction of the anterior cruciate ligament using a double bundle. Arthroscopy. 2000; $16: 860-4$

31. Pederzini L, Adriani E, Botticella C, Tosi M. Technical note: double tibial tunnel using quadriceps tendon in anterior cruciate ligament reconstruction. Arthroscopy. 2000;16:E9.

32. Yamamoto Y, Hsu WH, Woo SL, Van Scyoc AH, Takakura Y, Debski RE. Knee stability and graft function after anterior cruciate ligament reconstruction: a comparison of a lateral and an anatomical femoral tunnel placement. Am J Sports Med. 2004;32:1825-32.

33. Harner CD, Poehling GG. Double bundle or double trouble? Arthroscopy. 2004;20(:1013-4

34. Krackow KA, Thomas SC, Jones LC. A new stitch for ligament-tendon fixation. Brief note. J Bone Joint Surg Am. 1986;68:764-6.

35. Krackow KA, Thomas SC, Jones LC. Ligament-tendon fixation: analysis of a new stitch and comparison with standard techniques. Orthopedics. 1988;11:909-17.

36. Alm A, Liljedahl SO, Stromberg B. Clinical and experimental experience in reconstruction of the anterior cruciate ligament. Orthop Clin North Am. 1976;7:181-9.

37. Amatuzzi MM, Gouveia JLF, Padilha OS. Tratamento cirúrgico das instabilidades anteriores crônicas do joelho. [Surgical treatment of chronic anterior instabilities of the knee]. Rev Bras Ortop. 1986;21:3743.
38. Amatuzzi MM, Gouveia JLF, Padilha OS. O uso do ligamento patelar no tratamento das lesões antigas do ligamento cruzado anterior. Avaliação de 5 anos. In: Curso de Patologia do Joelho. Instituto de Ortopedia e Traumatologia do Hospital das Clínicas da Faculdade Medicina da Universidade de São Paulo; 1988. [Apostila].

39. Buss DD, Warren RF, Wickiewicz TL, Galinat BJ, Panariello R. Arthroscopically assisted reconstruction of the anterior cruciate ligament with use of autogenous patellar-ligament grafts. Results after twentyfour to forty-two months. J Bone Joint Surg Am. 1993;75:1346-55.

40. Eriksson E. Reconstruction of the anterior cruciate ligament. Orthop Clin North Am. 1976;7:167-79.

41. Jones KG. Reconstruction of the anterior cruciate ligament using the central one-third of the patellar ligament. A follow-up report. J Bone Joint Surg Am. 1970;52:1302-8.

42. Jones KG. Results of use of the central one-third of the patellar ligament to compensate for anterior cruciate ligament deficiency. Clin Orthop Relat Res. 1980;147:39-44.

43. Lam SJS. Reconstruction of the anterior cruciate ligament using the Jones procedure and its Guy's Hospital modification. J Bone Joint Surg Am. 1968;50:1213-22.

44. Lambert KL. Vascularized patellar tendon graft with rigid internal fixation for anterior cruciate ligament insufficiency. Clin Orthop Relat Res. 1983;172:85-9.

45. Lipscomb AB, Johnston RK, Snyder RB. The technique of cruciate ligament reconstruction. Am J Sports Med. 1981;9:77-81.

46. O'Brien SJ, Warren RF, Pavlov H, Panariello R, Wickiewicz TL. Reconstruction of the chronically insufficient anterior cruciate ligament with the central third of the patellar ligament. J Bone Joint Surg Am. 1991;73:278-86.

47. Paterson FW, Trickey EL. Anterior cruciate ligament reconstruction using part of the patellar tendon as a free graft. J Bone Joint Surg Br. 1986;68:453-7.

48. Ritter MA, Leaming ES, McCarroll JR. Preliminary report on the Jones, Ellison, Slocum (JES) repair for symptomatic anterior cruciate deficient knees. Am J Sports Med. 1983;11:89-94.

49. Tibone JE, Antich TJ. A biomechanical analysis of anterior cruciate ligament reconstruction with the patellar tendon. A two year followup. Am J Sports Med. 1988;16:332-5.

50. Odensten M, Gillquist J. Functional anatomy of the anterior cruciate ligament and a rationale for reconstruction. J Bone Joint Surg Am. $1985 ; 67: 257-62$

51. Hefzy MS, Grood ES, Noyes FR. Factors affecting the region of most isometric femoral attachments. Part II: The anterior cruciate ligament. Am J Sports Med. 1989;17:208-16.

52. O'Meara PM, O'Brien WR, Henning CE. Anterior cruciate ligament reconstruction stability with continuous passive motion. The role of isometric graft placement. Clin Orthop Relat Res. 1992;277:201-9.

53. Radford WJ, Amis AA, Kempson SA, Stead AC, Camburn M. A comparative study of single- and double-bundle ACL reconstructions in sheep. Knee Surg Sports Traumatol Arthrosc. 1994;2:94-9. 
54. Kaplan MJ, Howe JG, Fleming B, Johnson RJ, Jarvinen M. Anterior cruciate ligament reconstruction using quadriceps patellar tendon graft. Part II. A specific sport review. Am J Sports Med. 1991;19:458-62.

55. Fulkerson JP, Langeland R. An alternative cruciate reconstruction graft: the central quadriceps tendon. Arthroscopy. 1995;11:252-4.

56. Harris NL, Smith DA, Lamoreaux L, Purnell M. Central quadriceps tendon for anterior cruciate ligament reconstruction. Part I: Morphometric and biomechanical evaluation. Am J Sports Med. $1997 ; 25: 23-8$

57. Howe JG, Johnson RJ, Kaplan MJ, Fleming B, Jarvinen M. Anterior cruciate ligament reconstruction using quadriceps patellar tendon graft. Part I. Long-term followup. Am J Sports Med. 1991;19:447-57.

58. Staubli HU, Schatzmann L, Brunner P, Rincon L, Nolte LP. Quadriceps tendon and patellar ligament: cryosectional anatomy and structural properties in young adults. Knee Surg Sports Traumatol Arthrosc. 1996;4:100-10.

59. Staubli HU, Schatzmann L, Brunner P, Rincon L, Nolte LP. Mechanical tensile properties of the quadriceps tendon and patellar ligament in young adults. Am J Sports Med. 1999;27:27-34.

60. Lerat JL, Dupré-Latour L, Tarquini C, Dumont P. Remplacement des deux ligaments croisés avec un transplant unique provenant du système extenseur. Ligamentoplastie quadricipitale bicroisée. [Replacement of both cruciate ligaments with a single transplant from the extensor system. Bicross quadricipital ligamentoplasty]. Rev Chir Orthop Reparatrice Appar Mot. 1986;72:223-6.
61. Jones KG. Reconstruction of the anterior cruciate ligament. a technique using the central one-third of the patellar ligament. J Bone Joint Surg Am. 1963;45:925-32

62. Dejour H, Chambat P. La chirurgie ligamentaire du genou. In: Encycl. Med. Chir. Techniques chirurgicales orthopédie. Paris: Ed. Techniques; 1978. 4.2.06, 44790. Apud Dejour H, Chambat P. 1980. p. 727.

63. Dejour H, Chambat P. Las laxitudes crónicas anteriores. In: Lesiones de la rodilla. Madrid: Mapfre; 1980. p. 721-9.

64. Dejour H, Chambat P, Aglietti P. Ligamentous surgery of the knee. In: Insall JN, editor. Surgery of the knee. New York: Churchill-Livingstone; 1984. p. 353-93.

65. Rossi JDMBA, Leivas TP, Moré ADO, Camanho GL, Montenegro NB, Machado JWR. Ligamento cruzado anterior e tendão patelar: estudo mecânico e correlações clínicas. [Anterior cruciate ligament and patellar tendon: mechanical study and clinical correlations]. Rev Bras Ortop. 1990;25:197-201

66. Noyes FR, Butler DL, Grood ES, Zernicke RF, Hefzy MS Biomechanical analysis of human ligament grafts used in knee-ligament repairs and reconstructions. J Bone Joint Surg Am. 1984;66:344-52.

67. Miura K, Woo SL, Brinkley R, Fu YC, Noorani S. Effects of knee flexion angles for graft fixation on force distribution in double-bundle anterior cruciate ligament grafts. Am J Sports Med. 2006;34:577-85. 